\title{
Encystment of the red tide flagellate Chattonella antiqua (Raphidophyceae): cyst yield in batch cultures and cyst flux in the field
}

\author{
Yasuo Nakamura ${ }^{1}$, Tatsushi Umemori ${ }^{2, *}$ \\ ${ }^{1}$ Coastal Environment Research Team, National Institute for Environmental Studies, Tsukuba, Ibaraki 305, Japan \\ ${ }^{2}$ College of Agriculture and Veterinary Medicine, Nihon University, Setagaya, Tokyo 154, Japan
}

\begin{abstract}
In order to clarify the encystment conditions for the red tide flagellate Chattonella antiqua, cyst yield in batch cultures under a variety of environmental treatments and cyst flux in natural populations were monitored. In laboratory culture experiments, attempts were made to form 'small cells' (gametes) and cysts under nutrient-replete conditions, but they could not be formed without $\mathrm{N}$ - or P. depletion. Once small cells were formed by nutrient depletion, encystment was affected by environmental conditions. Cyst production was highest under continuous darkness and decreased with increasing light intensity. The optimum temperature range for encystment was 21.6 to $\geq 26.6^{\circ} \mathrm{C}$, broader than that for maximum growth rate. Cyst production increased linearly with increase in motile cell concentration, indicating that the efficiency of encystment was independent of motile cell concentration. Re-addition of nutrients to $\mathrm{N}$ - or P-depleted cultures did not affect cyst production. In the field, cyst flux of Chattonella spp. together with environmental variables were monitored throughout the blooming period of C. antiqua in the Seto Inland Sea, Japan. Cysts were formed mainly below a depth of $15 \mathrm{~m}$ when nutrients were exhausted in the $C$ antiqua habitat $(0$ to $10 \mathrm{~m})$ and the population was decreasing. Based on laboratory culture experiments and field observations, a simple model for encystment in the field was proposed. Following the development of the bloom, nutrients in the habitat of $C$. antiqua were exhausted and small cells were formed due to $\mathrm{N}$ - or P-depletion. Since small cells have a tendency to sink, they descended to the lower layer $(>15 \mathrm{~m}$ ) where environmental conditions were more favorable for encystment than in the upper layer (i.e. lower irradiance, optimal temperature, and replete nutrients do not affect encystment), and cysts were formed through the fusion of small cells below $15 \mathrm{~m}$. However, the possibility that small cells are formed without nutrient depletion cannot be completely ruled out, so the above model is not conclusive.
\end{abstract}

\section{INTRODUCTION}

In the last 2 decades, red tides due to Chattonella antiqua (Raphidophyceae) have occurred sporadically during summer in the Seto Inland Sea, Japan (Ono \& Takano 1980, Nakamura et al. 1989). Such blooms kill farmed fish, especially yellowtail, and the damage reached 30 million dollars during the red tide of 1972 (Iwasaki 1979). In order to assess the roles of chemical substances [such as $\mathrm{N}$ - and P-nutrients (N,P-nutrients), vitamin $B_{12}$ and trace metals] in inducing these red tides, we have monitored the marine environment around the Ie-shima Islands (Seto Inland Sea) each summer since 1985 and conducted bioassay and

\footnotetext{
- Present address: Tokyo Kyuei Co., Kawaguchi, Saitama 333, Japan
}

laboratory culture experiments. The results from these field surveys and experiments (Nakamura et al. 1988, 1989, Nakamura 1990) revealed that: (1) N,P-nutrients in the surface layer $(0$ to $5 \mathrm{~m})$ were insufficient to support rapid growth of $C$. antiqua, but those below the nutrient cline were sufficient; (2) vitamin $B_{12}$, essential for the growth of $C$. antiqua, did not become a growthrate-limiting factor; (3) Fe in the surface layer $(0 \mathrm{~m})$ was usually insufficient to support the maximum growth rate, but it was not as severely deficient as were $\mathrm{N}$ and/ or $\mathrm{P}_{i}$ (4) $\mathrm{Cu}_{\text {, whose toxicity to phytoplankton species }}$ may regulate the structure of the phytoplankton community, was always detoxified by natural organic ligand(s); and (5) the presence of a shallow nutrient cline $(5$ to $10 \mathrm{~m})$, coupled with the ability of $C$. antiqua to migrate vertically and take up nutrients at night, played an important role in the development of the red 
present study is shown in Table 1 . Maintenance and inoculum cultures were grown in TH medium (Table $1_{i}$ Nakamura et al. 1990). The strains (cell conc. $=\mathrm{ca}$ $2 \times 10^{4} \mathrm{ml}^{-1}$ ) were inoculated into experimental medium in combination $\left(0.5 \mathrm{ml} \mathrm{l}^{-1}\right.$ of each strain) and cultured at $25^{\circ} \mathrm{C}$ with $150 \mu \mathrm{E} \mathrm{m}^{-2} \mathrm{~s}^{-1}$ illumination under a $12 \mathrm{~h}$ light: $12 \mathrm{~h}$ dark photoperiod. In most cases, encystment experiments were started when the cultures reached the growth maximum ['small' cell ( $\leq 40 \mu \mathrm{m}$ ) fraction $=10$ to $20 \%$ of motile cells] by dividing the culture into subcultures (100 $\mathrm{ml}$ each; see below)

General method for encystment. Since cysts of Chattonella antiqua have a tendency to adhere to the surface of solid materials (Imai \& Itoh 1988), cysts were formed on the surface of microscope coverslips (Nakamura et al. 1990). Four coverslips $(15 \mathrm{~mm}$ in diameter, $1.8 \mathrm{~cm}^{2}$, made of borosilicate glass) were placed into a $200 \mathrm{ml}$ Erlenmeyer flask with a $100 \mathrm{ml}$ of distilled water and autoclaved. The distilled water was then discarded and replaced with $100 \mathrm{ml}$ of $C$ antiqua culture. The culture was incubated under a given experimental condition for a minimum of $6 \mathrm{~d}$, since this represents the interval after which total cyst counts do not increase (Nakamura et al. 1990). At the end of this interval, each coverslip was taken from the culture and rinsed in filtered seawater to remove motile cells, and the surface was observed using a microscope. The number of cysts adhering to the 4 coverslips was counted and converted to the cyst yield (cysts $\mathrm{cm}^{-2}$ ).

Small-cell concentrations were also monitored by microscope just before the start of the encystment experiment and after the end of incubation.

Attempts to form cysts under $\mathrm{N}$ - and P-sufficient conditions. Before examining the cyst yield as a function of environmental variables, some attempts were made to form cysts in the absence of nutrient depletion. Three experiments were conducted:

(1) A mixed culture of A-0 and B-20 (1 l) was grown in P-encystment medium (1.5 $\left.\mu \mathrm{M} \mathrm{PO}_{4}{ }^{3-}\right)$ under normal conditions $\left(25^{\circ} \mathrm{C}, 150 \mu \mathrm{E} \mathrm{m}^{-2} \mathrm{~s}^{-1}, 12 \mathrm{~h}\right.$ light: $12 \mathrm{~h}$ dark). When the culture was in exponential phase (no small cells), 5 subcultures $(100 \mathrm{ml} \times 5)$ were established and placed in darkness $\left(25^{\circ} \mathrm{C}\right)$ for $7 \mathrm{~d}$. The remaining culture $(500 \mathrm{ml})$ was further incubated under the normal conditions until growth reached a maximum (Pdepleted). Then, the culture was divided into 5 subcultures and placed in darkness $\left(25^{\circ} \mathrm{C}\right)$ for $7 \mathrm{~d}$.

(2) A mixed culture of A-0 and B-20 (1.5 l) was grown in $\mathrm{TH}$ medium under the normal culture conditions. When the cells were growing exponentially (ca $2.5 \times$ $10^{3}$ cells $\mathrm{ml}^{-1}$ ), the culture was divided into 3 parts. These parts were placed under high-light $(450 \mu \mathrm{E}$ $\mathrm{m}^{-2} \mathrm{~s}^{-1}, 25^{\circ} \mathrm{C}, 12 \mathrm{~h}$ light: $12 \mathrm{~h}$ dark), high-temperature $\left(150 \mu \mathrm{E} \mathrm{m} \mathrm{m}^{-2} \mathrm{~s}^{-1}, 28^{\circ} \mathrm{C}, 12 \mathrm{~h}\right.$ light: $12 \mathrm{~h}$ dark), and normal conditions respectively, for $2 \mathrm{~d}$. Then each part was divided into 5 subcultures and placed in darkness $\left(25^{\circ} \mathrm{C}\right)$ for $6 \mathrm{~d}$.

(3) Precultured Chattonella antiqua (mixture of $\mathrm{A}-0$ and $\mathrm{B}-20$; cell conc $\left.=3.7 \times 10^{3} \mathrm{ml}^{-1}\right)$ in medium with a low Fe content $\left(\mathrm{Ni}\right.$-metals $=0.38 \mathrm{ml} \mathrm{l}^{-1}$; Tris omitted; other components at levels for TH medium; see Table 1) was inoculated (ca $1 \mathrm{ml}$ ) into Fe-encystment medium (1 l). When the culture reached growth maximum, it was divided into 10 subcultures. Five were placed in darkness $\left(25^{\circ} \mathrm{C}\right)$ for $7 \mathrm{~d}$ to form cysts, and the other 5 were used to ensure that the encystment experiment was conducted under Fe-deficient conditions: 3 received Fe-enrichment $\left(0.2 \mu \mathrm{M}\right.$, as $\left.\mathrm{FeCl}_{3}\right)$, while the others did not. These were then incubated under normal conditions, and growth was monitored.

Effects of light, temperature and motile cell concentration. When light was an experimental variable, a mixed culture of A-0 and B-20 [2 l; grown in P-encystment medium (1 $\left.\mu \mathrm{M} \mathrm{PO}_{4}{ }^{3-}\right)$; at growth maximum and P-depleted] was divided into 18 subcultures and placed in a $3 \times 6$ latticed box (interior blackened) with irradiance from below (12 h light: 12 h dark) through a layer of neutral nylon cloth. Light intensity was adjusted by varying the number of layers $(6$ irradiances, 0 to $150 \mu \mathrm{E} \mathrm{m}^{-2} \mathrm{~s}^{-1}$, measured under water inside the culture flasks with a Biospherical Instruments QSL-100 probe). These subcultures were then incubated at $25^{\circ} \mathrm{C}$ for $7 \mathrm{~d}$.

When temperature was an experimental variable, a mixed culture of $\mathrm{A}-0$ and $\mathrm{B}-20 \quad[2.5 \mathrm{l}$; grown in Pencystment medium (1 $\left.\mu \mathrm{MPO}_{4}{ }^{3-}\right)$; at growth maximum and P-depleted] was divided into 24 subcultures, wrapped with aluminum foil and placed in incubators ( 3 flasks at each of 8 temperatures, range 17.7 to $26.6^{\circ} \mathrm{C}$ ) for $8 \mathrm{~d}$.

When cell concentration was an experimental variable, 12 subcultures with 4 different concentrations $(0.9$ to $4.5 \times 10^{3}$ cells $\mathrm{ml}^{-1}$ ) were established from a mixed culture of A-0 and B-20 [1 l; grown in P-encystment medium (1.5 $\left.\mu \mathrm{M} \mathrm{PO}_{4}{ }^{3-}\right)$; at growth maximum and $\mathrm{P}$ depleted] by diluting the culture with TH medium from which $\mathrm{N}$ and $\mathrm{P}$ were omitted. These subcultures were incubated in darkness $\left(25^{\circ} \mathrm{C}\right)$ for $7 \mathrm{~d}$.

Nutrient re-addition effects. A mixed culture fo A-0 and B-20 (1 $l_{\text {; }}$ grown in $\mathrm{N}$-encystment medium; at growth maximum and $\mathrm{N}$-depleted) was divided into 9 subcultures. The remaining culture was used for isolation of small cells (see below). Nutrients were then added to the subcultures. The modes of enrichment were: control (no addition), $+\mathrm{N}\left(10 \mu \mathrm{M} \mathrm{NO}_{3}{ }^{-}\right)$, and $+\mathrm{N}$ and $\mathrm{P}\left(10 \mu \mathrm{MNO}_{3}{ }^{-}\right.$and $\left.1 \mu \mathrm{M} \mathrm{PO}_{4}{ }^{3-}\right)$. After enrichment, the subcultures were incubated at $25^{\circ} \mathrm{C}$ with $150 \mu \mathrm{E}$ $\mathrm{m}^{-2} \mathrm{~s}^{-1}$ illumination for $3 \mathrm{~h}$ and then placed in darkness $\left(25^{\circ} \mathrm{C}\right)$ for $7 \mathrm{~d}$. Nutrient re-addition effects were also examined using P-depleted cultures [1 1 ; grown in 
P-encystment medium $\left(1 \mu \mathrm{M} \mathrm{PO}_{4}{ }^{3-}\right)$; at growth maximum and P-depleted]. The modes of enrichment were control, $+\mathrm{P}\left(1 \mu \mathrm{M} \mathrm{PO}_{4}{ }^{3-}\right)$ and $+\mathrm{N}$ and $\mathrm{P}\left(10 \mu \mathrm{M} \mathrm{NO}_{3}{ }^{-}\right.$ and $\left.1 \mu \mathrm{M} \mathrm{PO}_{4}{ }^{3-}\right)$. Other experimental procedures were the same as those described above.

Morphological changes in the small cells formed in the $\mathrm{N}$ - or P-depletd cultures were monitored under nutrient-sufficient conditions. From the remainder of $\mathrm{N}$ - or P-depleted cultures, small cells were isolated using a Pasteur pipette and placed into the wells of a tissue culture plate (Sumitomo Co., 96 wells) with $0.25 \mathrm{ml}$ well $^{-1}$ of $\mathrm{N}_{1} \mathrm{P}$-reduced $\mathrm{TH}$ medium $(10 \mu \mathrm{M}$ $\mathrm{NO}_{3}{ }^{-}$and $1 \mu \mathrm{MPO}_{4}{ }^{3-}$ ). Isolated cells were incubated at $25^{\circ} \mathrm{C}$ under darkness or $150 \mu \mathrm{E} \mathrm{m}^{-2} \mathrm{~s}^{-1}$ illumination (12 h light: $12 \mathrm{~h}$ dark) for $4 \mathrm{~d}$. Morphological changes in the cells were monitored daily using an inverted microscope.

Vertical distribution of small cells. A mixed culture of A-0 and B-20 $\left[2 l_{i}\right.$ grown in P-encystment medium $\left(1.5 \mu \mathrm{M} \mathrm{PO}_{4}{ }^{3-}\right)_{i}$ P-depleted $;$ small cell fraction $=$ ca $40 \%$ of motile cells] was transferred to 2 cylindrical glass tubes ( $25 \mathrm{~cm}$ high by $8 \mathrm{~cm}$ i.d., sides and bottom blackened) One received nutrient enrichment $\left(10 \mu \mathrm{M} \mathrm{NO}_{3}{ }^{-}\right.$and $1 \mathrm{MMPO}_{4}{ }^{3-}$ ) and the other did not. After thorough mixing of the cultures, they were placed in the normal culture conditions (lights on at 08:00 h and off at 20:00 h) at 13:00 $\mathrm{h}$. On the following day, water samples (ca $3 \mathrm{ml}$ ) were taken from the 'upper', 'middle' and 'bottom' layer (Watanabe et al. 1983) at 00:30 h and 11:30 h. Concentrations of small cells $(\leq 40 \mu \mathrm{m})$ were measured by microscope counts using a $1 \mathrm{ml}$ Sedgewick-Rafter chamber with appropriate dilutions if necessary. As a control, vertical distributions of exponentially growing cells in TH medium were also monitored.

\section{Field survey}

Monitoring of marine environment. In summer 1989 (20 July to 13 August), field surveys were conducted at Stn B (depth $=21 \mathrm{~m}$ ) around the le-shima Islands in the Seto Inland Sea (see Nakamura et al. 1988). Water temperature and salinity were monitored daily at $2.5 \mathrm{~m}$ intervals using a Surveyor Il (Hydrolab Co.). Transparency (Secchi depth) was monitored daily. Water samples for chemical analysis $\left[\mathrm{NO}_{3}{ }^{-}, \mathrm{NO}_{2}{ }^{-}, \mathrm{PO}_{4}{ }^{3-}\right.$. $\mathrm{Si}(\mathrm{OH})_{4}$, chlorophyll a] and enumeration of Chattonella antiqua and $C$. marina cells were taken daily from depths of $0,5,10,15$ and $19 \mathrm{~m}$ using a $10 \mathrm{l}$ Van Dorn type bottle. Samples for vitamin $B_{12}$ analysis were obtained using the same bottle from depths of 0,10 and $19 \mathrm{~m}$ at $3 \mathrm{~d}$ intervals. Monitoring and sampling were conducted in the morning (08:30 to 09:30 h) and water samples were treated (filtration, enumeration of cells, etc.) immediately in our field laboratory (Nakamura et al. 1988). Analytical procedures for each chemical variable have been summarized in previous papers (Nakamura et al. 1988, 1989). Concentrations of $C$. antiqua and $C$ marina cells were measured by observing $1 \mathrm{ml}$ of the intact seawater sample in a SedgewickRafter chamber using a microscope.

Cyst trap. In order to monitor the flux of Chattonella spp. cysts (cysts of $C$. antiqua are morphologically indistinguishable from those of C. marina: Imai \& Itoh 1988), sediment trap bottles $(50 \mathrm{~cm}$ high by $10 \mathrm{~cm}$ i.d., made of acrylic acid resin) were immersed daily from 5 to 12 August (except on 6 August) at depths of 15 and $19 \mathrm{~m}$ in the afternoon (ca 14:00 h). At each depth, 2 bottles were placed in a cage suspended from the surface by nylon rope and a buoy. The following day, trap bottles were recovered (ca 13:30 h) and all but ca $650 \mathrm{ml}$ of the supernatant was removed by siphoning on board. Two trap samples from the same depth were combined into a 2 I polypropylene bottle and carried to our field laboratory.

At the field laboratory, trap samples were sieved through $20 \mu \mathrm{m}$ netting, washed with and suspended in filtered seawater, and poured into a graduated cylinder for volume measurement. Then the samples were introduced into $100 \mathrm{ml}$ polyethylene bottles, stored at $10^{\circ} \mathrm{C}$ in the dark until the end of the survey period and carried to our institute (ca $10^{\circ} \mathrm{C}$, in the dark).

Cysts were enumerated, using an epifluorescence microscope, by observing autofluorescence under bluelight excitation irrespective of degree of maturation (Imai \& Itoh 1988). The samples were placed in a PalmerMaloney counting chamber $(0.18 \mathrm{ml})$ and enumeration was conducted at least 10 times for each sample.

\section{RESULTS}

\section{Encystment in laboratory cultures}

Attempts to form cysts under nutrient-replete conditions

Results of experimental attempts to form cysts under $N$ - and P-sufficient conditions are summarized in Table 2. When an exponentially growing culture (growth rate $=0.7 \mathrm{~d}^{-1}$ ) in P-encystment medium was transferred to the dark, no cysts were formed and essentially no cells survived. In contrast, following P-depletion in the same culture, transfer to the dark induced encystment and a significant fraction of the cells (especially small cells) survived after dark incubation (Table 2)

We hypothesized that a rapid increase in temperature or light intensity would cause formation of small cells (precursors of cysts) under nutrient-replete conditions. Although these treatments caused retardation 


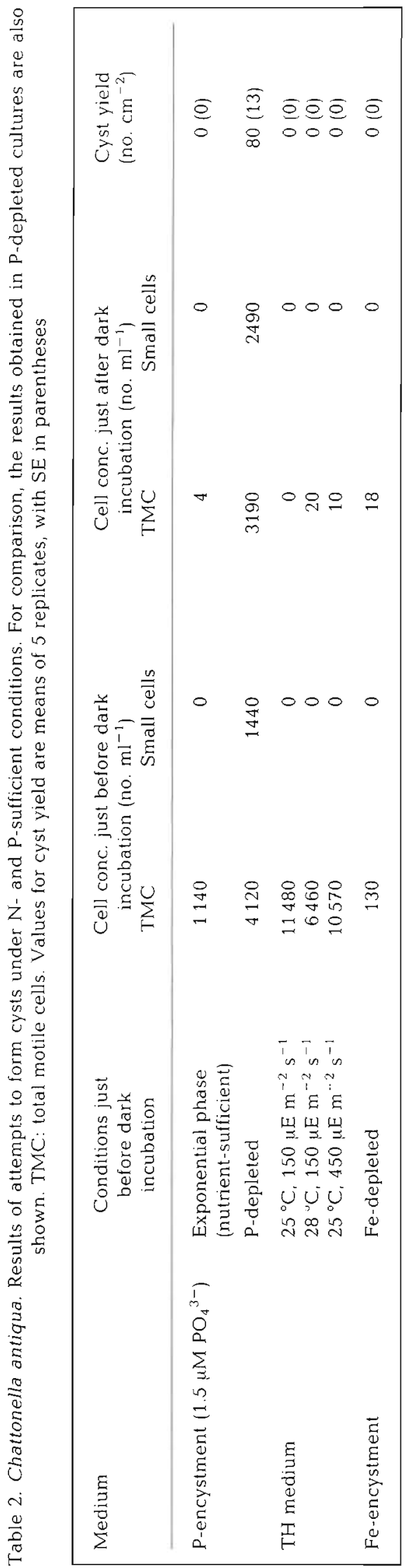

of the growth rate (temperature shift) or a slight swelling of the cells (light shift), no small cells were formed. Following these treatments, the cultures were transferred to the dark, but no cysts were formed (Table 2)

Another attempt to form cysts under N,P-replete conditions was conducted using an Fe-limited culture. Although Fe-enrichment to the culture revived the growth, indicating that the culture was Fe-depleted (data not shown), small cells were not observed before transfer to the dark and cysts were not formed (Table 2).

Cyst yield under environmental and nutritional stress

Cyst yield was strongly affected by light intensity (Fig. 1). The yield decreased steadily with light intensity. However, encystment was not inhibited completely even under the maximum light intensity examined $\left(150 \mu \mathrm{E} \mathrm{m} \mathrm{m}^{-2} \mathrm{~s}^{-1}\right.$; yield $\left.=1 \mathrm{cyst} \mathrm{cm}^{-2}\right)$. Although total motile cell concentrations after the incubation were 50 to $75 \%$ of the initial values (data not shown), concentrations of small cells after the incubation were higher than the initial value ( 250 cells $\mathrm{ml}^{-1}$ ) at each irradiance level and did not show any systematic trend with irradiance (Fig. 1).

In the temperature range examined $\left(17.6\right.$ to $\left.26.6^{\circ} \mathrm{C}\right)$, cyst yield ranged from 6 to 67 cysts $\mathrm{cm}^{-2}$, with the highest production at and above $21.6^{\circ} \mathrm{C}$ (Fig. 2). The concentration of small cells after the incubation appeared to vary in conjunction with cyst yield, except at $26.6^{\circ} \mathrm{C}$, and was higher than the initial value $(310$ cells $\mathrm{ml}^{-1}$ ) at all temperatures examined.

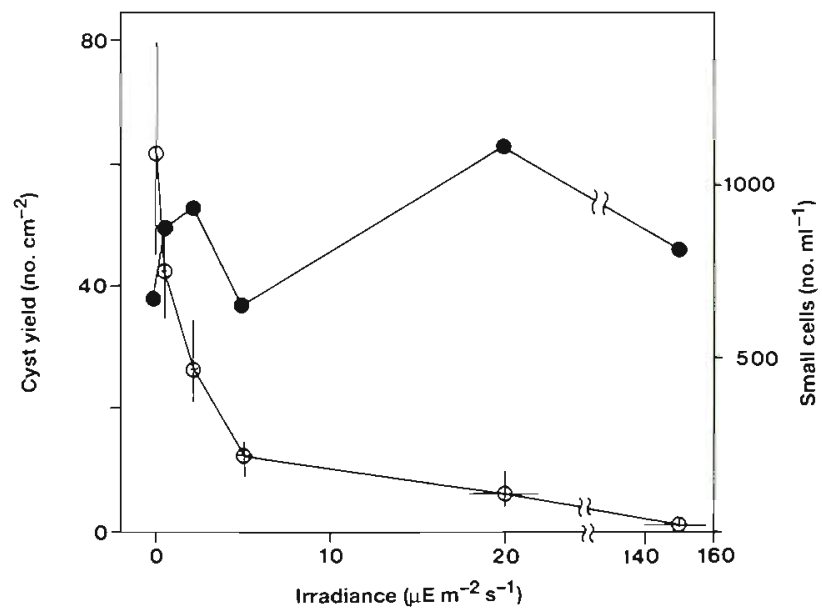

Fig. 1 Chattonella antiqua. Effect of irradiance on cyst yield $(0)$ and on small-cell concentration after incubation (•). Vertical error bars show the range of triplicate counts of cysts; horizontal error bars indicate the range of irradiance fluctuations 


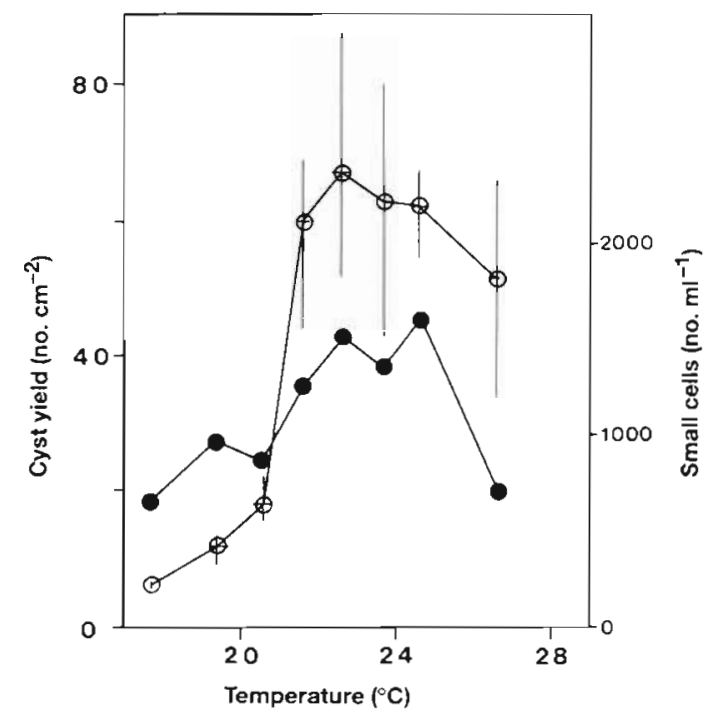

Fig. 2. Chattonella antiqua. Effect of temperature on cyst yield $(0)$ and small-cell concentration after incubation ( $\bullet$ ). Vertical error bars show the range of triplicate counts of cysts; horizontal error bars indicate the range of temperature fluctuations

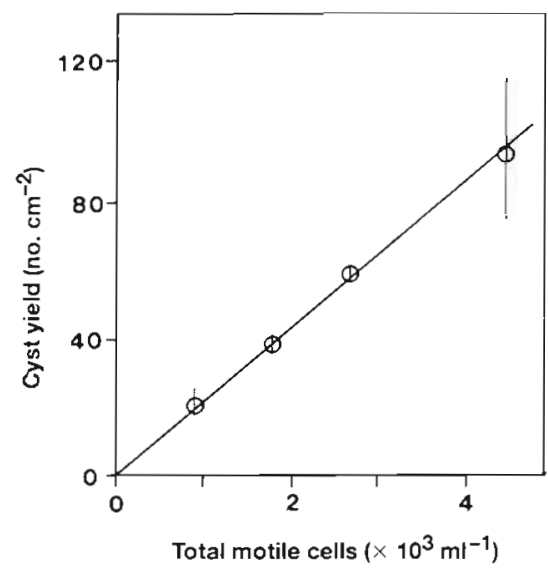

Fig. 3. Chattonella antiqua. Effect of total motile cell concentration on cyst yield. Vertical error bars show the range of triplicate counts
Cyst yield increased linearly with total motile cell concentration (Fig. 3). In other words, encystment efficiency was constant and no cell-concentration-dependent effects were apparent.

Nutrient re-addition to $\mathrm{N}$ - or P-depleted cultures did not affect the cyst yield significantly (Table 3 ). Irrespective of nutrient re-addition, small-cell concentrations after the incubation were higher than the initial value

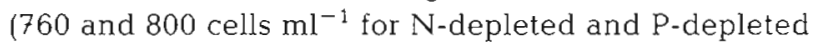
cultures, respectively). Furthermore, small cells isolated from $\mathrm{N}$ - or P-depleted cultures and placed into $\mathrm{N}$ and P-replete medium did not become large (vegetative) cells again, irrespective of light conditions (12 h light: $12 \mathrm{~h}$ dark, or darkness). Division of small cells was not observed.

\section{Vertical distribution of small cells}

In an attempt to explain the field observation that small cells were only found near the bottom layer isee below), the vertical distributions of small cells in a cylindrical tube were examined. Although an exponentially growing culture displayed vertical migration, small cells always accumulated at the bottom irrespective of nutrient enrichment (Table 4).

\section{Field observations}

In summer 1989, we conducted a field survey around the Ie-shima Islands (20 July to 13 August). Vertical profiles of environmental variables throughout the survey period are summarized in Table 5 . A small red tide due to Chattonella antiqua was observed from 7 to 11 August (Fig. 4A; see also Fig. 5). The bloom occurred on 7 August and the vegetative cell concentration averaged over the water column reached a maximum on 8 August $\left(47\right.$ cells $\left.\mathrm{ml}^{-1}\right)$. Thereafter, the population decreased rather rapidly to 2 cells $\mathrm{ml}^{-1}$ on 12 August

Table 3. Chattonella antiqua. Effects of nutrient re-addition to nutrient-depleted cultures on cyst yield (no. $\mathrm{cm}^{-2}$ ) and small-cell concentrations (no $\mathrm{ml}^{-1}$ )

\begin{tabular}{|c|c|c|c|c|}
\hline Culture & Treatment & $\begin{array}{l}\text { Small-cell conc before } \\
\text { dark incubation }\end{array}$ & Cyst yield ${ }^{\circ}$ (SE) & $\begin{array}{l}\text { Small-cell conc. after } \\
\text { dark incubation }{ }^{b}\end{array}$ \\
\hline$N$-depleted & $\begin{array}{c}\text { Control } \\
+N \\
+N \text { and } P\end{array}$ & $\begin{array}{l}760 \\
760 \\
760\end{array}$ & $\begin{array}{l}48(6) \\
45(3) \\
47(3)\end{array}$ & $\begin{array}{l}1550 \\
2040 \\
2240\end{array}$ \\
\hline P-depleted & $\begin{array}{c}\text { Control } \\
+\mathrm{P} \\
+\mathrm{N} \text { and } \mathrm{P}\end{array}$ & $\begin{array}{l}800 \\
800 \\
800\end{array}$ & $\begin{array}{l}76(14) \\
76(15) \\
69(6)\end{array}$ & $\begin{array}{l}1370 \\
1670 \\
2070\end{array}$ \\
\hline
\end{tabular}


Table 4. Chattonella antiqua. Vertical distributions of small cells and vegetative cells (no. $\mathrm{ml}^{-1}$ ) in cylindrical bottles under $12 \mathrm{~h}$ light:12 h dark. For each sample the number of hours into the light ( $\mathrm{L}$ ) or dark (D) period is shown (e.g. $5.0 \mathrm{~L}=5 \mathrm{~h}$ after the light went on)

\begin{tabular}{|lccrc|}
\hline Sampling period & Sampling layer & $\begin{array}{c}\text { Small cells } \\
\text { (P-depleted) }\end{array}$ & $\begin{array}{c}\text { Small cells } \\
\text { (nutrients re-added) }\end{array}$ & $\begin{array}{c}\text { Vegetative cells } \\
\text { (exponential phase) }\end{array}$ \\
\hline Day 1, 13:00 h (5.0 L) & Mixed & 1820 & 1820 & 940 \\
Day 2, 00:30 h (4.5 D) & Upper & 20 & 60 & 150 \\
& Middle & 10 & 30 & 110 \\
Day 2, 11:30 h (3.5 L) & Lower & 56900 & 38200 & 22300 \\
& Upper & 30 & 10 & 12850 \\
Day 2, $14: 00 \mathrm{~h} \mathrm{(6.0} \mathrm{L)}$ & Lower & 147600 & 217600 & 120 \\
& Mixed & 1800 & 1410 & 400 \\
\hline
\end{tabular}

Table 5. Vertical profiles of environmental variables at Stn B from 20 July to 13 August 1989 . Secchi depth during this period changed from 5.5 to $9 \mathrm{~m}$ (avg. $=7.4 \mathrm{~m}$ ). Values in parentheses are averages of each parameter throughout the survey period

\begin{tabular}{|c|c|c|c|c|c|c|c|c|}
\hline $\begin{array}{l}\text { Depth } \\
\text { (m) }\end{array}$ & $\begin{array}{l}\text { Temp. } \\
\left({ }^{\circ} \mathrm{C}\right)\end{array}$ & $\begin{array}{c}\mathrm{S} \\
(\% \circ)\end{array}$ & $\begin{array}{l}\mathrm{NO}_{3}{ }^{-} \\
(\mu \mathrm{M})\end{array}$ & $\begin{array}{l}\mathrm{NO}_{2}^{-} \\
(\mu \mathrm{M})\end{array}$ & $\begin{array}{c}\mathrm{PO}_{4}{ }^{3-} \\
(\mu \mathrm{M})\end{array}$ & $\begin{array}{l}\mathrm{Si}(\mathrm{OH})_{4} \\
(\mu \mathrm{M})\end{array}$ & $\begin{array}{c}B_{12} \\
\left(\text { ng } 1^{-1}\right)\end{array}$ & $\begin{array}{c}\text { Chl a } \\
\left(\mu \mathrm{gl}^{-1}\right)\end{array}$ \\
\hline 0 & $\begin{array}{c}24.0-26.4 \\
(25.0)\end{array}$ & $\begin{array}{c}31.0-32.2 \\
(31.6)\end{array}$ & $\begin{array}{c}<0.1-1.9 \\
(0.4)\end{array}$ & $\begin{array}{c}<0.1-0.2 \\
(0.1)\end{array}$ & $\begin{array}{c}<0.01-0.32 \\
(0.05)\end{array}$ & $\begin{array}{c}2.7-10.3 \\
(7.3)\end{array}$ & $\begin{array}{c}2.2-4.1 \\
(3.1)\end{array}$ & $\begin{array}{c}0.7-5.8 \\
(2.4)\end{array}$ \\
\hline 5 & $\begin{array}{c}23.5-26.3 \\
(24.7)\end{array}$ & $\begin{array}{c}31.0-32.2 \\
(31.7)\end{array}$ & $\begin{array}{c}<0.1-1.6 \\
(0.6)\end{array}$ & $\begin{array}{c}<0.1-0.3 \\
(0.1)\end{array}$ & $\begin{array}{c}<0.01-0.14 \\
(0.04)\end{array}$ & $\begin{array}{c}2.6-11.6 \\
(7.4)\end{array}$ & - & $\begin{array}{c}1.0-6.5 \\
(2.5)\end{array}$ \\
\hline 10 & $\begin{array}{c}22.5-26.1 \\
(24.4)\end{array}$ & $\begin{array}{c}31.2-32.3 \\
(31.8)\end{array}$ & $\begin{array}{c}<0.1-3.7 \\
(1.2)\end{array}$ & $\begin{array}{c}<0.1-0.8 \\
(0.3)\end{array}$ & $\begin{array}{c}0.01-0.25 \\
(0.09)\end{array}$ & $\begin{array}{l}3.1-15.6 \\
(9.1)\end{array}$ & $\begin{array}{c}2.8-3.7 \\
(3.1)\end{array}$ & $\begin{array}{c}0.9-4.6 \\
(2.2)\end{array}$ \\
\hline 15 & $\begin{array}{c}21.2-25.0 \\
(23.7)\end{array}$ & $\begin{array}{c}31.6-32.5 \\
(31.9)\end{array}$ & $\begin{array}{c}0.5-9.0 \\
(3.2)\end{array}$ & $\begin{array}{c}0.1-1.3 \\
(0.5)\end{array}$ & $\begin{array}{c}0.03-0.43 \\
(0.23)\end{array}$ & $\begin{array}{c}5.3-27.5 \\
(14.5)\end{array}$ & - & $\begin{array}{c}0.9-2.9 \\
(1.8)\end{array}$ \\
\hline 19 & $\begin{array}{c}21.1-24.2 \\
(23.0)\end{array}$ & $\begin{array}{c}31.7-32.5 \\
(32.0)\end{array}$ & $\begin{array}{c}1.1-9.3 \\
(4.7)\end{array}$ & $\begin{array}{c}0.3-1.4 \\
(0.7)\end{array}$ & $\begin{array}{c}0.29-2.64 \\
(0.71)\end{array}$ & $\begin{array}{c}6.6-39.6 \\
(22.9)\end{array}$ & $\begin{array}{c}1.9-3.7 \\
(2.7)\end{array}$ & $\begin{array}{c}1.4-3.3 \\
(2.3)\end{array}$ \\
\hline $\begin{array}{l}\text { Bottom } \\
(21 \mathrm{~m})\end{array}$ & $\begin{array}{c}21.0-24.1 \\
(22.8)\end{array}$ & $\begin{array}{c}31.6-32.5 \\
(32.0)\end{array}$ & & & & & & \\
\hline
\end{tabular}

(see Fig. 5). During the blooming period, other phytoplankton species were rather scarce.

Changes in the concentration of Chattonella antiqua vegetative cells and in temperature and nutrients $\left(\mathrm{NO}_{3}{ }^{-}, \mathrm{PO}_{4}{ }^{3-}\right)$ from just before until the end of the bloom ( 5 to 13 August) are shown in Fig. 4. Throughout this period, temperature was optimum for $C$ antiqua growth (Nakamura \& Watanabe 1983a, K. Yamanaka unpubl.). In the period from pre-initiation to bloom development (5 to 8 August), concentrations of nitrate and phosphate in the surface layer $(0$ to $5 \mathrm{~m}$ ) were relatively high and comparable to the half-saturation constants for growth of $C$. antiqua $\left(K_{\mathrm{g}}\right)$ for these nutrients $\left(K_{\mathrm{g}} \mathrm{NO}_{3}=1 \mu \mathrm{M}, K_{\mathrm{g}}{ }^{\mathrm{PO}_{4}}=0.11 \mu \mathrm{M}\right.$; Nakamura et al. 1988). After this period, nutrients were exhausted in the surface layer. Nutrient concentrations at $10 \mathrm{~m}$ were higher than $K_{\mathrm{g}}$ 's from 5 to 8 August and decreased after 9 August (except on 10 August). Below $15 \mathrm{~m}$, nutrients stayed at high levels irrespective of bloom development.
On 7 and 8 August, vegetative cells of Chattonella antiqua appeared healthy in terms of size (ca $100 \mu \mathrm{m}$ ) and color, and accumulated in the surface layer in the morning. However, in the period of bloom decline, cells became smaller (ca $80 \mu \mathrm{m}$ ) and looked pale, and their distribution was shifted downward (Fig. 4). Furthermore, small cells (ca $30 \mu \mathrm{m}$ ) were observed on 10 and 11 August at $19 \mathrm{~m}$, at concentrations of 19 and 170 cells $\mathrm{ml}^{-1}$, respectively. 'Fusing' pairs of small cells were also found. Except for this period and layer, no small cells or 'fusing' pairs were observed during the entire survey period. C. marina, whose cysts are morphologically indistinguishable from those of C. antiqua (Imai \& Itoh 1988), were scarce $\left(\leq 2\right.$ cells $\left.\mathrm{ml}^{-1}\right)$ from 5 to 12 August. A colorless dinoflagellate, Gyrodinium sp., which contained debris of $C$. antiqua, was apparent after 10 August (cell concentrations $=\mathrm{ca} 10$ to 100 cells $\mathrm{ml}^{-1}$ ), but quantitative enumeration was not conducted.

Changes in Chattonella spp. cyst flux (5 to 13 


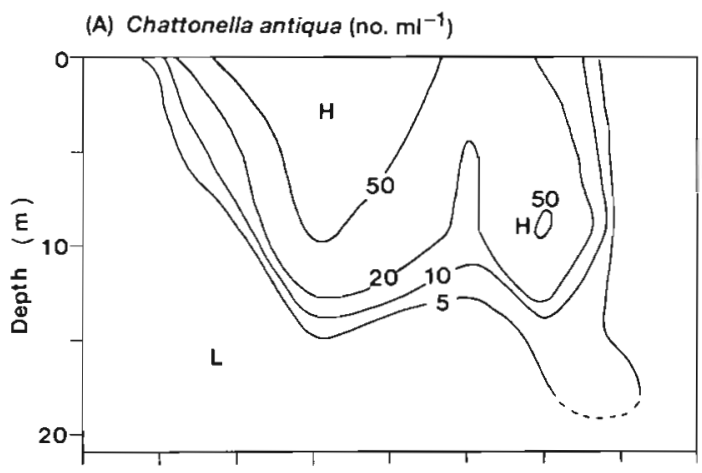

(B) Temperature $\left({ }^{\circ} \mathrm{C}\right)$

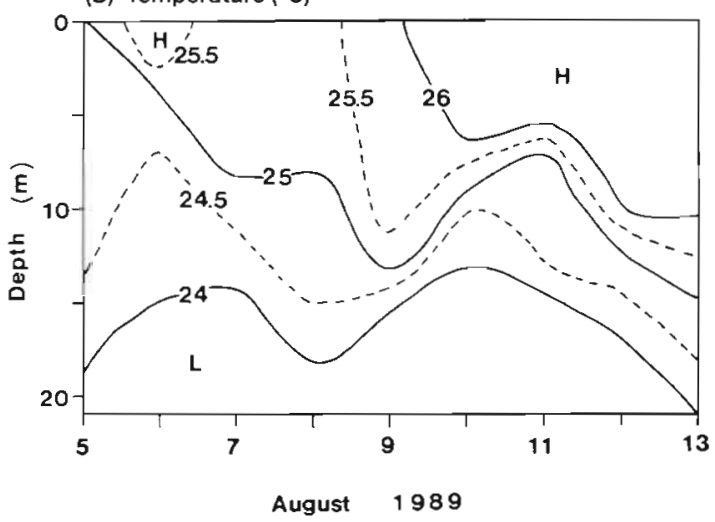

(C) $\mathrm{NO}_{3}^{-}(\mu \mathrm{M})$
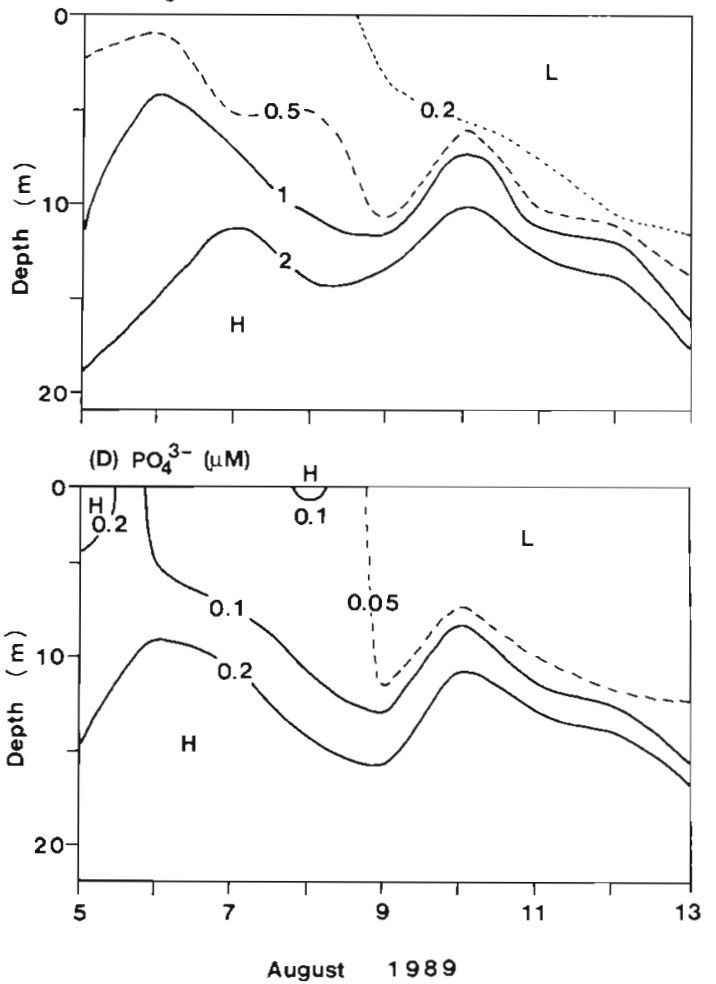

Fig. 4. Chattonella antiqua. Bloom outbreak time series at Stn B. (A) Vegetative cell concentration; (B) temperature; (C) nitrate concentration; (D) phosphate concentration. $\mathrm{H}$ : high; $\mathrm{L}$ : low

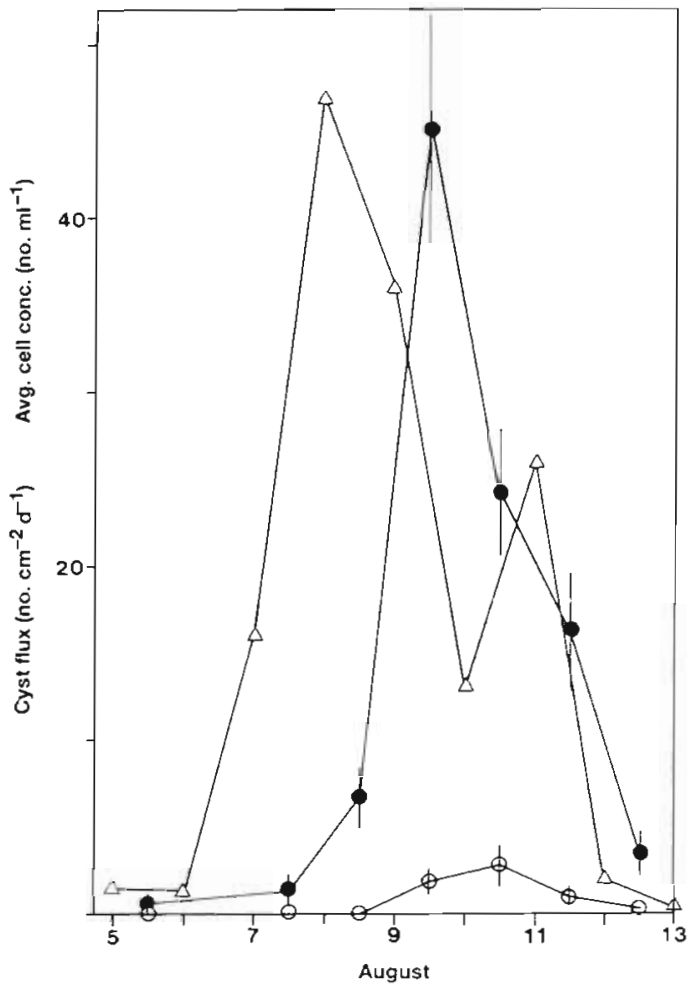

Fig. 5. Chattonella spp. Time series for cyst flux (O: $15 \mathrm{~m}$; $19 \mathrm{~m}$ ) and average concentrations of $C$. antiqua vegetative cells ( $L$ ) over the water column at Stn B. Vertical error bars show the SE accompanying cyst enumeration
August) are shown in Fig. 5. The number of cysts at $19 \mathrm{~m}$ showed small values ( $\leq 1.5$ cysts $\mathrm{cm}^{-2} \mathrm{~d}^{-1}$ ) during the pre-bloom and bloom-development periods $(5$ to 8 August), increased rapidly to reach a sharp maximum between 9 and 10 August (bloom-declining period; 45 cysts $\mathrm{cm}^{-2} \mathrm{~d}^{-1}$ ) and then decreased. The total flux at $19 \mathrm{~m}$ for the period was $98 \mathrm{~cm}^{-2}$, comparable to the cyst concentration in the bottom sediment of the Seto Inland Sea (Imai \& Itoh 1985). Cyst flux at $15 \mathrm{~m}$ showed a slight maximum in the bloom-declining period ( 3 cysts $\mathrm{cm}^{-2} \mathrm{~d}^{-1}$ ), but was negligible in comparison with that at $19 \mathrm{~m}$. These results indicate that cysts of Chattonella spp. were formed mainly below $15 \mathrm{~m}$ in the bloomdeclining period of the 1989 red tide.

\section{DISCUSSION}

As shown previously (Nakamura et al. 1990), cysts of Chattonella antiqua are formed through the sexual fusion of small cells (gametes). In the present study, small cells were observed only in $\mathrm{N}$ - or P-depleted cultures, in spite of attempts to form them under nutrient-replete conditions. Once small cells were formed by nutrient depletion, total cyst yield was influenced by temperature and light conditions, but not by the readdition of nutrients. In the field, the cysts were formed 
mainly below $15 \mathrm{~m}$ in the bloom-declining period when nutrients were exhausted in the $C$. antiqua habitat $(0$ to $10 \mathrm{~m}$ ). These observations seem to be consistent with the laboratory results.

\section{Laboratory experiments}

It is well known that a reduction in nutrient concentrations is often effective in inducing gamete formation and encystment (e.g. Pfiester 1975, Turpin et al. 1978, Anderson et al. 1984, 1985, Anderson \& Lindquist 1985). Within the scope of the present study, cysts of Chattonella antiqua were obtained only in $\mathrm{N}$ - or $\mathrm{P}$ depleted cultures. No small cells were observed in the cultures without nutritional stress (exponentially growing or having undergone a light/temperature shift), and transfer of these cultures to the dark resulted in mortality of vegetative cells (Table 2). On the other hand, small cells formed under $\mathrm{N}$ - or P-depleted conditions survived in the dark (Tables $2 \& 3$ ). These findings, together with the observation that small cells did not revert to the vegetative state in nutrient-replete conditions, indicate that small cells were physiologically differentiated from nutrient-replete vegetative cells.

Since we used non-axenic cultures of Chattonella antiqua, one might conjecture that bacteria could have broken down Tris buffer (see Table 1) to ammonium and that small cell formation in $\mathrm{N}$-encystment medium. (see Table 3) occurred under $\mathrm{N}$-sufficient conditions. However, the results of our preliminary experiments showed that motile cell (= vegetative plus small cell) concentration at the growth maximum in $\mathrm{N}$-encystment medium (5 to $20 \mu \mathrm{M} \mathrm{NO}{ }^{-}$) increased almost linearly with initial nitrate concentrations (Umemori 1990). Thus, we do believe that small-cell formation in the $\mathrm{N}$ encystment medium occurred under $\mathrm{N}$-depleted conditions even if some ammonium liberated from Tris was utilized by $C$. antiqua.

Since iron in the surface layer in summer around the le-shima Islands is usually insufficient to support rapid growth of Chattonella antiqua (Nakamura 1990), and Fe limitation induces encystment in the dinoflagellate Alexandrium tamarense (Doucette et al. 1989), we tried to form cysts in Fe-limited cultures (Table 2). Although the total motile cell concentration before dark incubation (130 cells $\mathrm{ml}^{-1}$ ) was much lower than that in Pencystment medium (4120 cells $\mathrm{ml}^{-1}$; Table 2 ), small cells were not found and no cysts were detected in 5 replicate counts (i.e. 20 coverslips; $35 \mathrm{~cm}^{2}$ ). If we assume that the efficiency of encystment in Fedepleted cultures is not very different from that in $\mathrm{P}$ depleted cultures (cyst yield $=80$ cysts $\mathrm{cm}^{-2}$; Table 2 ), the expected cyst yield in the former would be $80 \times$ $(130 / 4120)=2.5$ cysts $\mathrm{cm}^{-2}$, much higher than the observed value (no cysts in a $35 \mathrm{~cm}^{2}$ area). Although the possibility of $C$. antiqua forming cysts under $\mathrm{Fe}$ depleted conditions cannot be ruled out completely due to the low population density used, we conclude that the efficiency of small-cell formation and encystment under Fe-limited conditions is much less than that in $\mathrm{P}$ - (and $\mathrm{N}$-) depleted conditions.

In some phytoplankton species, sexual reproduction occurs under nutrient-replete conditions (e.g. Wall et al. 1970, Nozaki 1986, Montresor \& Zingone 1988) and our attempts to form cysts without $\mathrm{N}$, P-depletion were rather restricted. Thus, it is too early to conclude that small cells and cysts are formed only under $\mathrm{N}$ - or Pdepleted conditions. However, it should be stressed that nutrient depletion is at least one important factor for small-cell formation by $C$. antiqua.

As shown in Fig. 1, the cyst yield was at a maximum under darkness and decreased with increasing light intensity. These trends have also been observed for Chattonella marina (Imai 1989) and explain inferentially the field observations that cysts were formed mainly in the lower irradiance layer (> $15 \mathrm{~m}$; Fig. 5). The concentration of small cells after incubation did not show any trends with irradiance, suggesting that low cyst production at high irradiance was not due to the mortality of small cells, but to the inhibition of cell fusion.

Vegetative growth of Chattonella antiqua was positive above $15^{\circ} \mathrm{C}$, with maximum growth rate occurring in the range of 24 to $27^{\circ} \mathrm{C}$, and cell mortality was observed at $31^{\circ} \mathrm{C}$ (Nakamura \& Watanabe 1983a, K. Yamanaka unpubl.). At $21.6^{\circ} \mathrm{C}$, the lower temperature limit for the highest level of cyst production, the growth rate was about $60 \%$ of the maximum. Although the upper temperature limit for the highest level of cyst production was not determined and the strains used in the present study (A-0 and B-20) were different from that used for growth rate measurements (Ho-1), the range for the highest cyst production $\left(21.6\right.$ to $\geq 26.6{ }^{\circ} \mathrm{C}$; Fig. 2) is apparently wider than that for growth

One might expect encystment efficiency to be optimal at or above a specific cell concentration, with the lowest values at reduced cell concentrations, where interaction between small cells (gametes) would be less frequent. However, the linear relationship between cyst yield and motile cell concentration (Fig. 3) indicates that encystment efficiency was constant across a wide range of motile cell concentrations. Relatively constant encystment efficiency was also observed in $\mathrm{N}$ or P-limited cultures of Gonyaulax tamarensis (Anderson et al. 1984). Unfortunately, we cannot presently make any conclusive statements about the constancy of encystment efficiency.

In the field, cysts of Chattonella spp. were formed mainly in the nutrient-replete layer (Figs. 4 \& 5). In 
contrast, cysts were not formed in laboratory cultures without nutrient depletion, within the scope of the present study. In order to explain this discrepancy, nutrient re-addition effects were examined (Table 3 ). The results indicated that once small cells have been formed under $\mathrm{N}$ - or $\mathrm{P}$-depleted conditions, the process cannot be reversed and their ability to form cysts is maintained even if ambient nutrient concentrations increase again.

The concentrations of small cells in $\mathrm{N}$ - or P-depleted cultures (and nutrient re-addition cultures) after dark incubation were higher than those before dark incubation (Tables 2 \& 3). This indicates that small cells continued to be formed in the dark, and that most of the small cells did not participate in encystment. Since small cells were tentatively defined as cells $\leq 40 \mu \mathrm{m}$ in length, some of them might have been nutrientdepleted vegetative cells (which cannot become encysted). In addition, encystment of Chattonella antiqua is completed within $3 \mathrm{~d}$ after transfer to the dark (Nakamura et al. 1990). The formation process for small cells, duration of their fusing ability, and differentiation of gametes from small vegetative cells should be clarified in order to understand the encystment process on a biological basis.

\section{Field observations}

In comparison with the Chattonella antiqua red tide in 1987 (Nakamura et al. 1989), the magnitude and distribution of the 1989 red tide were rather limited ( $\mathrm{S}$. Yoshimatsu pers. comm.). Furthermore, the occurrence of the 1989 red tide around the Ie-shima Islands was coupled with the decline of the bloom at the northern edge of the Seto Inland Sea (Futami fishing harbor, $30 \mathrm{~km}$ from the Ie-shima Islands; $H$. Kobayashi pers. comm.), suggesting that the sudden occurrence of the bloom (7 August 1989) was due (partly) to advection.

In spite of the great difference in the magnitude of red tides between these 2 years, changing patterns of environmental variables in 1989 from just before initiation to the termination of the bloom ( 5 to 13 August) resembled those in 1987 . In both years, temperature and vitamin $\mathrm{B}_{12}$ were optimal throughout the period (cf. Nakamura \& Watanabe 1983a, Nakamura et al. 1988). $\mathrm{N}$ - and P-concentrations at or above $10 \mathrm{~m}$ were relatively high just before bloom initiation and during the bloom-developing period, and nutrients were exhausted in the Chattonella antiqua habitat 10 to $10 \mathrm{~m}$; Hamamoto et al. 1979. Nakamura et al. 1989) during the bloom-declining period (Fig. 4). However, in contrast to the 1987 red tide, nutrients at or below $15 \mathrm{~m}$ were not exhausted and the decline of the bloom was apparently coupled with the grazing of $C$. antiqua by the colorless dinoflagellate Gyrodinium sp. The cyst flux data are discussed below with reference to the changes in environmental variables.

Turbid bottom water is widely present in the Seto Inland Sea and resuspension of the bottom sediments is considered to be the cause of the turbidity (Kawana \& Tanimoto 1984). Thus, one might consider that cyst flux at $19 \mathrm{~m}\left(\mathrm{~F}_{19}\right)$ was strongly affected by the resuspension of the cysts in the bottom sediment. However, it should be noted that $F_{19}$ was very small ( $\leq 3$ cysts $\mathrm{cm}^{-2} \mathrm{~d}^{-1}$ ) before the initiation of the bloom (5 to 6 August), in the development period ( 7 to 8 August) and after termination (12 to 13 August) (Fig. 5). In addition, since the weather was sunny and calm between 8 and 11 August (the period when $F_{19}$ showed high values), as well as during the other period of cyst-trap experiments (leshima Weather Monitoring Station, Meteorological Agency, Japan), it is unlikely that resuspension of the cysts between 8 and 11 August was greater than in the other period. We conclude that the contribution of resuspension to $F_{19}$ was negligible.

Cysts of Chattonella antiqua are morphologically indistinguishable from those of $C$. marina (Imai \& Itoh 1988) and the cyst flux observed was the total for the 2 species. However, vegetative cells of C. marina were scarce $\left(\leq 2\right.$ cells $\mathrm{ml}^{-1}$ ) during the period of cyst-trap experiments and its contribution to the flux was probably negligible.

Since encystment of Chattonella antiqua is affected markedly by irradiance levels (Fig. 1), comparison of the light intensity between 15 and $19 \mathrm{~m}$ (i.e. the depth where traps were immersed) is important for interpretation of the cyst flux data (Fig. 5). Although light intensities were not measured in the 1989 survey, light attenuation with depth was monitored once a day in 1990 (21 July to 13 August; no red tides; Nakamura unpubl.) and light intensities at 15 and $19 \mathrm{~m}$ in 1989 were roughly estimated as follows. Using the daily total irradiance data at Osaka $100 \mathrm{~km}$ from the Ie-shima Islands; Meteorological Agency, Japan) and light attenuation data, light intensities averaged over the daytime period at depths of 15 and $19 \mathrm{~m}\left(\mathrm{I}_{1.5}\right.$ and $\left.\mathrm{I}_{19}\right)$ in 1990 were calculated. Since light attenuation coefficients were correlated with Secchi depth (6 to $18.5 \mathrm{~m}$; Nakamura unpubl.) and the weather during the trap experiments was sunny as in 1990, it is reasonable to assume that $I_{1 s}$ and $I_{19}$ during the period of trap experiments (5 to 13 August 1989; Secchi depth $=5$ to $8 \mathrm{~m}$ ) were not very different from those when Secchi depths were in the range of 6 to $8.5 \mathrm{~m}$ in 1990 . Based on this assumption, estimated values of $\mathrm{I}_{15}$ and $\mathrm{I}_{19}$ during the cyst-trap experiments were 12 (5 to 19) and $1.4(0.2$ to 4) $\mu \mathrm{E} \mathrm{m}^{-2} \mathrm{~s}^{-1}$, respectively. As shown in Fig. 1, cyst yields at the irradiance levels at $15 \mathrm{~m}\left(12 \mu \mathrm{E} \mathrm{m}^{-2} \mathrm{~s}^{-1}\right)$ and $19 \mathrm{~m}\left(1.4 \mu \mathrm{E} \mathrm{m} \mathrm{m}^{-2} \mathrm{~s}^{-1}\right)$ were 15 and $55 \%$ of the 
maximum (at $0 \mu \mathrm{E} \mathrm{m}^{-2} \mathrm{~s}^{-1}$ ). In other words, encystment efficiency at $19 \mathrm{~m}$ is 3.7 times higher than that at $15 \mathrm{~m}$, and this difference partly explains the fact that cysts were mainly formed below $15 \mathrm{~m}$ (Fig. 5).

Based on the results obtained from the laboratory culture experiments and field observations, the cyst flux data (Fig. 5) seem to be explained consistently by the changes in the environmental variables, and a simple scenario for the encystment of Chattonella antiqua in the field can be drawn. Namely, following the development of the bloom, nutrients in the habitat of $C$. antiqua (0 to $10 \mathrm{~m}$ ) were exhausted (Fig. 4) and small cells were formed due to $\mathrm{N}$ - and/or P-depletion (Tables 2 \& 3). Since small cells have a tendency to sink (Table 4), they descended below $15 \mathrm{~m}$ depth. The observation that small cells were found only at $19 \mathrm{~m}$ in the bloomdeclining period (10 and 11 August) confirms the above reasoning. Below a depth of $15 \mathrm{~m}$, temperature was in the optimum range for encystment (Figs. $2 \& 4$ ) and replete nutrients (Fig. 4) did not affect the encystment ability of the small cells (Table 3 ). Furthermore, encystment efficiency increased with increasing depth (or decreasing light intensity) (Fig. 1), and light conditions above $15 \mathrm{~m}$ were somewhat inhibitory for encystment (see above). Thus, as shown in the cyst flux data (Fig 5), cysts were formed mainly below $15 \mathrm{~m}$ in the bloomdeclining period.

Although the above scenario for the encystment process in the field is apparently reasonable, there are some uncertainties with respect to the time required for encystment. In our time-course measurements of encystment in batch culture (Nakamura et al. 1990), it took 2 or $3 \mathrm{~d}$ for encystment following the formation of small cells. If this is also the case for the natural populations, the maximum cyst flux observed between 9 and 10 August (Fig. 5) was due to the small cells formed on 7 and 8 August, when nutrients at or above $10 \mathrm{~m}$ were not completely exhausted and Chattonella antiqua populations were developing (Fig. 4). In addition, sinking rates of small cells were not determined and the time required for small cells to reach a depth below $15 \mathrm{~m}$ is still unknown. In this context, the above scenario is not conclusive.

Laboratory culture results and field observations involving the red tide dinoflagellate Gonyaulax tamarensis are inconsistent. Cysts were not formed under nutrient-replete conditions in batch culture (Anderson et al. 1984, Anderson \& Lindquist 1985), whereas encystment in the field occurred under conditions seemingly favorable for growth (Anderson et al. 1983). Although the reason for the inconsistency observed in Chattonella antiqua and $G$. tamarensis has not yet been identified, one possible explanation is that it is due to the characteristics of batch culture. In batch culture, concentrations of limiting nutrient decrease rapidly to reach 'zero' (below the detection limit) with population growth, and it is difficult to examine smallcell (gamete) formation at nutrient levels in the growthrate-limiting range (ca $0.1 \mu \mathrm{M} \mathrm{PO}_{4}{ }^{3-}$ or $1 \mu \mathrm{M} \mathrm{NO}_{3}{ }^{-}$for C. antiqua; Nakamura et al. 1988). Continuous culture is needed in order to consider the possibility that $C$. antiqua may form small cells under conditions where ambient nutrient is not depleted but regulates growth.

Since cyst flux at $19 \mathrm{~m}$ changed drastically during the experimental period (5 to 13 August; Fig. 5), it would be interesting to monitor the cyst concentration in the bottom sediment throughout the blooming period. We are now planning to monitor the cyst concentrations in the bottom sediments by direct counting (total cysts) and by the extinction dilution method (germinative cysts) together with measurements of cyst flux.

In summary, encystment conditions of Chattonella antiqua obtained in laboratory cultures were used to explain the changes in Chattonella cyst flux. Although some uncertainties still remain with respect to the timing of small-cell formation, the observation that cysts were formed mainly below $15 \mathrm{~m}$ is explained well in terms of the conditions of irradiance, temperature and nutrients required for encystment.

Acknowledgements. The authors express their thanks to Drs S. Takeshita and K. Kohata for their encouragement. This study was supported by Grant-in-Aid No. 63740368 from the Scientific Research Fund of the Ministry of Education. Science and Culture, Japan

\section{LITERATURE CITED}

Anderson, D. M., Chisholm, S. W., Watras, C. J. (1983). Importance of life cycle events in the population dynamics of Gonyaulax tamarensis. Mar Biol. 76: 179-189

Anderson, D. M., Coats, D. W., Tyler, M. A. (1985). Encystment of the dinoflagellate Gyrodinium uncatenum: Temperature and nutrient effects. J. Phycol. 21:200-206

Anderson, D. M., Kulis, D. M., Binder, B. J. (1984). Sexuality and cyst formation in the dinoflagellate Gonyaulax tamarensis: cyst yield in batch cultures. J. Phycol. 20: 418-425

Anderson, D. M., Lindquist, N. L. (1985). Time course measurements of phosphorus depletion and cyst formation in the dinoflagellate Gonyaulax tamarensis Lebour. J exp. mar. Biol. Ecol. 86: 1-13

Anderson, D. M., Wall, D. (1978). The potential importance of benthic cysts of Gonyaulax tamarensis and Gonyaulax excavata in initiating toxic dinoflagellate blooms in the Cape Cod region. J. Phycol. 14: 224-234

Binder, B. J., Anderson, D. M. (1987). Physiological and environmental control of germination in Scrippsiella trochoidea (Dinophyceae) resting cysts. J. Phycol. 23: 99-107

Doucette, G. J., Cembella, A. D., Boyer, G. L. (1989). Cyst formation in the red tide dinoflagellate Alexandrium tamarense (Dinophyceae): effects of iron stress. J. Phycol. 25: 721-731

Hamamoto, S., Yoshimatsu, S., Yamada, T. (1979). Diurnal 
vertical migration of Hornellia (Chattonella antiqua) in the field. In: Okaichi, $T$ (eds.) Reports on the red tides due to Hornellia occurred in June, 1978. Kagawa Prefecture (Japan), Takamatsu, p. 42-44

Imai, I. (1989). Cyst formation of the noxious red tide flagellate Chattonella marina (Raphidophyceae) in culture. Mar. Biol. 103: 235-239

Imai, I., Itoh., K. (1985). Distribution of dormant cells of Chattonella in bottom sediments of Harima-Nada, eastern Seto Inland Sea, in April, 1984. Bull. Nansei reg. Fish. Res. Lab. 19: $43-52$

Imai, I., Itoh, K. (1987). Annual life cycle of Chattonella spp., causative flagellates of noxious red tides in the Inland Sea of Japan. Mar. Biol. 94: 287-292

Imai, I., Itoh, K. (1988). Cyst of Chattonella antiqua and $C$. marina in sediments of the Inland Sea of Japan. Bull. Plankton Soc. Japan 35: 35-44

Iwasaki, H. (1979). Physiological ecology of red tides. In: Levandowsky, M., Hutner, S. H. (eds.) Biochemistry and physiology of protozoa, Vol. 1. Academic Press, London, p. $357-393$

Kawana, K., Tanimoto, T (1984). Turbid bottom water layer and bottom sediment in the Seto Inland Sea. J. oceanogr Soc. Japan 40: 175-183

Montresor, M., Zingone, A. (1988). Scrippsiella precaria sp. nov. (Dinophyceae), a marine dinoflagellate from the Gulf of Naples. Phycologia 27: 387-394

Nakamura, Y (1990). Chemical environment for red tides due to Chattonella antiqua Part 3 . Roles of iron and copper. J. oceanogr. Soc. Japan 46: 84-95

Nakamura, Y., Takashima, J., Watanabe, M. (1988). Chemical environment for red tides due to Chattonella antiqua in the Seto Inland Sea, Japan Part 1. Growth bioassay of the seawater and dependence of growth rate on nutrient concentrations. J. oceanogr Soc. Japan 44: 113-1.24

Nakamura, Y., Umemori, T., Watanabe, M. (1989). Chemical

This article was submitted to the editor environment for red tides due to Chattonella antiqua Part 2. Daily monitoring of the marine environment throughout the outbreak period. J. oceanogr. Soc. Japan 45: 116-128

Nakamura, Y., Umemori, T., Watanabe, M., Kulis, D. M. Anderson, D. M. (1990). Encystment of Chattonella antiqua in laboratory cultures. J. oceanogr Soc. Japan 46: $35-43$

Nakamura, Y., Watanabe, M. M. (1983a). Growth characteristics of Chattonella antiqua (Raphidophyceae) Part 1. Efects of temperature, salinity, light intensity and $\mathrm{pH}$ on growth. J. oceanogr Soc. Japan 39: 110-114

Nakamura, Y., Watanabe, M. M. (1983b). Growth characteristics of Chattonella antiqua Part 2. Effects of nutrients on growth. J. oceanogr. Soc. Japan 39: 151-155

Nozaki, H. (1986). Sexual reproduction in Gonium sociale (Chlorophyta, Volvocales). Phycologia 25: 29-35

Ono, C., Takano, T (1980). Chattonella antiqua (Hada) comb. nov., and its occurrence on the Japanese coast. Bull. Tokai reg. Fish. Res. Lab. 102: 93-100

Pfiester, O. P. (1975). Sexual reproduction of Peridinium cinctum f. ovoplanum (Dinophyceae). J. Phycol. 11. 259-265

Turpin, D. H., Dobell, P. E. R., Taylor, F. J. R. (1978). Sexuality and cyst formation in Pacific strains of the toxic dinoflagellate Gonyaulax tamarensis. J. Phycol. 14: 235-238

Umemori, T. (1990). Life cycle studies on a red tide flagellate Chattonella antiqua. M.S. thesis, Nihon University, Japan (in Japanese)

Wall, D., Guillard, R. R. L., Dale, B., Swift, E., Watabe, N (1970). Calcitic resting cysts in Peridinium trochoideum (Stein) Lemmermann, an autotrophic marine dinoflagellate. Phycologia 9: 151-156

Watanabe, M. M., Nakamura, Y., Kohata, K. (1983). Diumal vertical migration and dark uptake of nitrate and phosphate of the red tide flagellates. Heterosigma akashiwo Hada and Chattonella antiqua (Hada) Ono (Raphidophyceae). Jap. J. Phycol. 31 161-166

Manuscript first received: June 18, 1991

Revised version accepted: October 28, 1991 